\title{
Bioenergy for regions - alternative cropping systems and optimisation of local heat supply
}

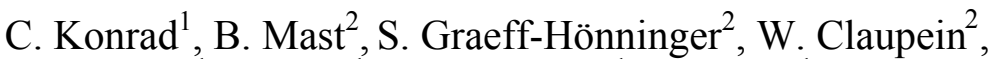 \\ R. Bolduan ${ }^{1}$, J. Skok ${ }^{1}$, J. Strittmatter ${ }^{1}$, M. Brulé ${ }^{1} \&$ G. Göttlicher ${ }^{3}$ \\ ${ }^{I}$ European Institute for Energy Research EIFER, Karlsruhe, Germany \\ ${ }^{2}$ Universität Hohenheim, Stuttgart, Germany \\ ${ }^{3}$ Energie Baden-Württemberg AG (EnBW), Karlsruhe, Germany
}

\begin{abstract}
In the frame of a research project for the energy supplier "Energie BadenWürttemberg AG" (EnBW) in Germany, the aim of the study is to evaluate the potentials of alternative substrates and their viability for biogas conversion based on current production regimes in the county of Biberach in the South-West of Germany. The project includes 5-yr field tests of optimized cropping systems leading to higher biodiversity and sustainability while ensuring a constant biomass supply for biogas production.

Furthermore precise calculations and estimations of the heat demand of rural areas have been made on an object-based level (residential and tertiary/industry) using a geographic information system (GIS). On the basis of existing biogas plants, techno-economical analysis of heat and micro gas networks have been performed.

Sustainability is mainly emphasized on the basis of the aspect of environmental influence on cropping systems (biodiversity, soil erosion, ground and surface water pollution). Biogas yield data at laboratory scale are used to evaluate the economy of alternative cropping systems with regard to energy production as compared to the reference (maize monoculture) in the whole chain ranging from field cultivation to energy use.

The practical feasibility and the environmental effects are reviewed in comprehensive and multi-field tests and field trials.

Keywords: biomass potential, yield model, GIS, biogas, substrate, biodiversity, heat demand, building stock, heat sinks, small district heating, micro gas grid.
\end{abstract}




\section{Introduction}

Biomass production for the conversion into biogas has become very popular since the establishment of the renewable energy law (EEG) in 2001. Currently there are already 5700 existing biogas plants in Germany. Most biogas plants run on maize as a main substrate, cultivated in monoculture over large areas. The one-sided specialisation on a specific crop goes along with several environmental problems such as the loss of biodiversity, soil erosion and the pollution of ground and soil water.

As the EEG generously supports the generation of renewable electricity, many biogas units are operated without using enough of the heat produced despite the combined heat and power (CHP) bonus. This research project focuses on finding alternatives cropping systems and alternative use of heat for a more sustainable development of current and future biogas installations.

\section{Estimation of the biomass potential}

According to the official statistics, about $10 \%$ of the agricultural land was used for the cultivation of energy crops in the county of Biberach in 2007 [5]. Meanwhile, this value has significantly increased to $15 \%$. From an ecological point of view, the problem is the increasing land use and thereby the competition with food production and animal feed production. The continuous and intensive use of agricultural areas with all the environmental consequences could lead to future deterioration of biodiversity. Actually the area used for the growth of energy crops is further increasing, focusing particularly on maize production. In relation to the entire cultivated area, the proportion of maize in 2009 reached about $30 \%$ in the county of Biberach. In several communes, even over $50 \%$ of cultivated land is used for the growth of silage maize [4]. The tendency is that this maize is the major substrate for biogas production. The rate of grassland useage for biogas production, which reaches only $3 \%$, is still quite low and surely remains an interesting potential which is not sufficiently used. The introduction of the public subvention "manure bonus" led to an extra created incentive in 2009 in the amendment of the renewable energy law (EEG). The use of slurry and manure builds up a further potential, which amounts to about 90,000 livestock units which can be partly used for the biogas production.

The estimation of the biomass potential is based on publications of the ministry of agriculture and on the official statistics of Baden-Württemberg [4, 5]. Moreover high-resolution remote sensing data is available to the project [3]. This data allows an accurate spatial differentiation of arable- and grassland units. The calculation of biogas and methane yields is based on empirical values of on-farm biogas plants [2]. In addition to the common energy crops like silage maize, grass silage and whole crop silage (WCS), the extended use of manure as a function of livestock units is considered (Figure 1). 
Biomass potential

Data source:

Remote sensing data [3],

official statistics $[4,5]$

Biomass yield

calculation_based on intermediate yield using estimated values[2]

Taken CHP efficiency; i.e. $\eta=39 \%$ electrical efficiency $\eta=52 \%$ thermal efficiency

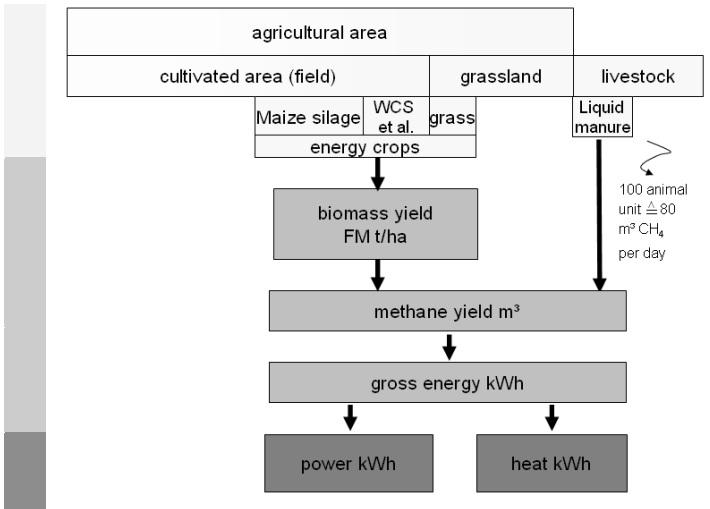

Figure 1: Schematic diagram of the estimation methodology of the biomass potential in the county of Biberach.

\subsection{Status quo of biogas production}

The characterisation of the installed biogas plants is based on information from the administration and the public database of EnBW [1]. Within this data the location and actual amount of electricity generated from biogas are documented. In the year 200974 biogas units with a rated power output of over $20 \mathrm{MW}_{\mathrm{el}}$ are already installed in Biberach. About two-thirds of the biogas plants are equipped with a combined heat and power system CHP. This means that besides the

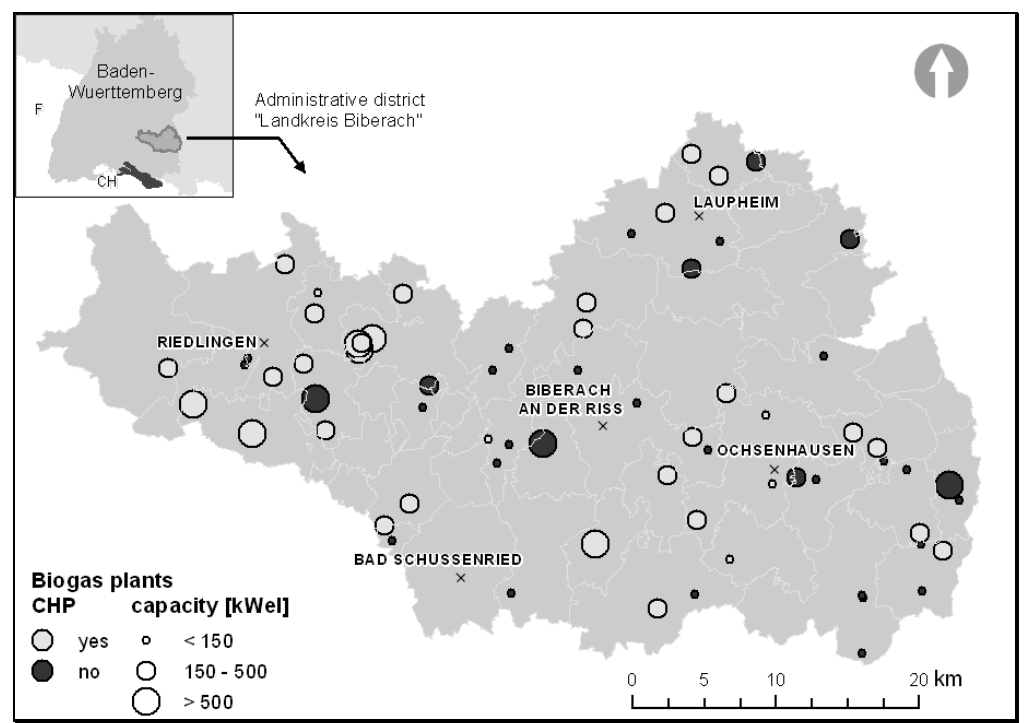

Figure 2: $\quad$ Location and capacity of biogas plants. 
electricity generation, the heat that they are producing is also used. In 2009 about $140 \mathrm{GWh}$ of electric power were fed into the grid whereby the comparison of registered rated power output to the actual electric production shows that most of the facilities are working below their installed capacities. This shows that fermenters and installed CHPs are not always fully optimised to each other. The equivalent electrical supply amounts of 50,000 households with an average annual electrical consumption for a two-person household of $2800 \mathrm{kWh}$.

\section{Alternative cropping systems and field experiments}

For biogas production in Germany maize is currently the major crop used, representing up to $90 \%$ of the biogas substrate [6]. The area under maize increased drastically over the last years; in 2009 maize intended for biogas production was cultivated on about 380,000 ha in Germany [7].

From an economical perspective, maize is a favorable crop on many sites, providing high energy yields per area and furthermore being an established crop with wide experience in cultivation and ensilage [8].

On the other hand, maize cropping systems are highly criticized. The strong focus of the agricultural practice on maize as the main biogas substrate entails also negative ecological impacts like soil erosion, soil organic matter reduction, nitrate leaching and the loss of biodiversity and habitats [9]. The Sachverständigenrat für Umweltfragen (German Advisory Council on the Environment) [6] estimated in its special report that maize is a crop with a high risk for nutrient leaching, soil erosion and biodiversity. Besides the effect on biodiversity, also the typical local agricultural biodiversity and landscape appearance is decreasing in regions where biogas plants are implemented.

Furthermore, diseases like Helminthosporium turcicum and pests like Diabrotica virgifera virgifera are increasing as a result of an intensive maize cultivation and thus are endangering stable and high biomass yields of maize. The occurrence of the western corn rootworm (Diabrotica virgifera virgifera) may cause yield losses as high as $30 \%$ and often results in a ban on maize cultivation in the specific area [10].

When discussing alternative crops and cropping systems for biogas production, the use of a temporal sequence of crops also including strips of perennial crops (e.g. energy dock, cup plant) offers multiple harvest dates and thus widens the temporal availability of the substrate for biogas plants and might furthermore reduce erosion potential and nutrient leaching. Laloy and Bielders [11] found that erosion is greatly reduced if a winter cover crop (rye and ryegrass) is cultivated during the intercropping period before maize (maximized soil cover) when compared to maize without a winter cover crop.

Results from Vetter [12] indicated that biodiversity (flora and fauna) is greater in cropping systems with two or three crop species than in a monoculture. However, these options are neither sufficiently perceived nor applied in agricultural practice [13]. 


\subsection{Implementation of alternative cropping systems in the study region}

The objective of this study lies in developing, testing and monitoring sustainable cropping systems offering a long-term alternative to maize as a biogas substrate in the region. The experimental field site of 5.6 ha is implemented on a farm located in the county of Biberach. The developed cropping system will be cultivated in this field with assistance from the farmer and different environmental relevant parameters will be collected and measured over four years. In 2010 the existing maize monoculture was monitored to determine the status quo situation, as a reference for conventional biogas crop cultivation. In the following four years, this field will be used for the cultivation of the intended alternative cropping system.

The following parameters are identified as relevant and measured:

- Fresh- and dry matter yield of the different crops

- Biogas output of the different crops

- Erosion potential

- Nitrate leaching into the groundwater

- Biodiversity (arable weed species, along transects which are distributed across the field)

- Biodiversity (ground beetles, with pit fall traps, which are distributed across the field)

\subsection{Developed cropping system}

The developed cropping system consists of a strip-wise cultivation of a perennial crop and annual crops in a crop rotation. Figure 3 shows the developed cropping system in comparison to a maize monoculture (M) without permanent soil coverage. For the perennial crop (pC) energy dock also known as Rumex Schavnat or Rumex OK2 will be used. It is a frost-resistant crossbreed from the Ukraine with a cultivation period of $15-20$ years and a potentially high biomass yield. Its biomass can be harvested twice a year and ensiled [14].

The implemented crop rotation (CR) includes the crop species sunflower (1 yr $+4 \mathrm{yr})$ - winter triticale $(2 \mathrm{yr})-$ clover grass $(2 \mathrm{yr}+3 \mathrm{yr})-$ amaranth $(3 \mathrm{yr})-$ forage rye $(4 \mathrm{yr})$, and it is set up completely without maize. As a further advantage, the developed cropping system allows a permanent soil cover with all the above-mentioned positive aspects. From the second year onwards energy dock could provide considerable higher biomass yields than other perennial crops. Furthermore the production costs are lower (seed, fertilizer, etc.) after the establishment phase in the first year. Strips of CR and pC will be of 24 m width and fit into the working width of the farmer's equipment.

The given combination and parallel cultivation of winter crops, summer crops and clover grass are expected to entail the above mentioned advantages and distribute the substrate supply over the year. This has a further positive effect of reducing silage storage capacity requirements. 


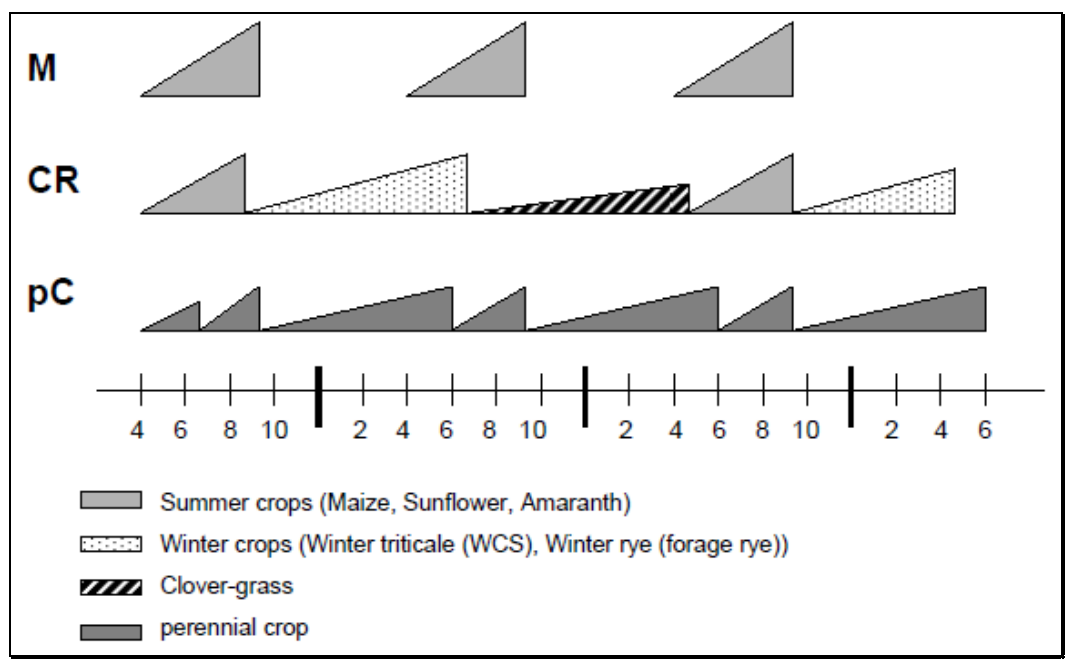

Figure 3: The cropping scheme (one run of the crop rotation) for the monoculture maize $(\mathrm{M})$, the alternative crop rotation $(\mathrm{CR})$ and the perennial crop (pC) (the axis of abscissa are the month of the years).

\section{Model for the biogas production from energy crop mixtures}

\subsection{Model objectives}

Energy crops of different varieties are amenable to anaerobic digestion. The crops which are most suitable for biogas production may be characterized with the following parameters:

1. High biomass yield per hectare (tons of dry mass $=\mathrm{DM}$ harvested per ha);

2. Low cultivation costs;

3. High digestibility (i.e. low fibre and lignin contents);

4. Appropriate $\mathrm{C}: \mathrm{N}$ ratio (i.e. ranging between 20 and 30) [15].

Because of its ability to fulfill these requirements, maize is currently the most wanted energy crop for anaerobic digestion [15]. However, the environmental drawbacks of maize motivate the search for alternative energy crops.

A model, based on the identified alternative cropping systems (Section 3) was developed in order to perform an assessment of energy crops for biogas production while comparing different crop varieties. For this purpose, data were collected on methane yields of energy crops (laboratory batch test) as well as on the biomass yield per hectare. Using the composition and weight ratios of energy crops in the digester feedstock as input parameters, the feedstock mixture composition can be calculated and compared to empirically set optimal criteria (C:N ratio, fibre and lignin content) for digester operation. Moreover, the methane yield per hectare of field can be determined. 


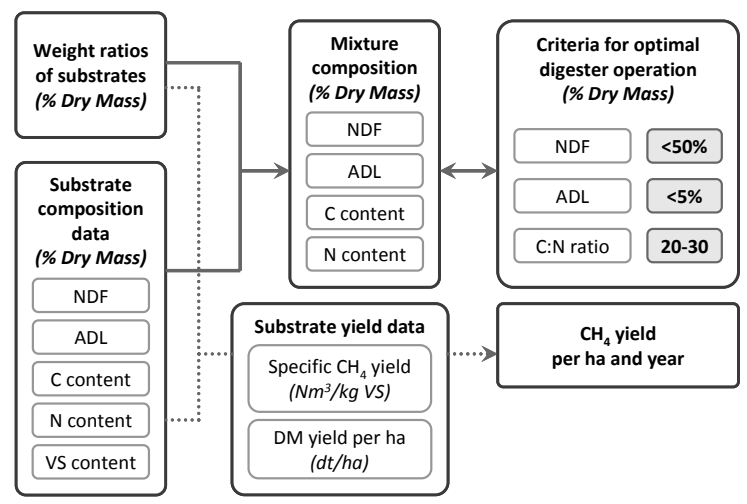

Figure 4: Input parameters (on the left) and output parameters of the model (on the right). NDF: neutral detergent fiber, ADL: Acid Detergent Lignin.

\subsection{Exemplary energy crop mixture}

Within this model a conventional cropping system based on maize monoculture was compared to an alternative and more sustainable cultivation system. The most methane yielding mixture was selected from the previously proposed cropping system (Figure 3). The high-yielding sustainable crop mixture was composed of $40 \%$ Triticale, 40\% Cup plant and 20\% Amaranth (all shares on a dry matter basis). Figure 5 shows the dry matter yield (on the left) and the methane yield (on the right). For both parameters maize, the alternative cropping system as well as the single crops is pictured.
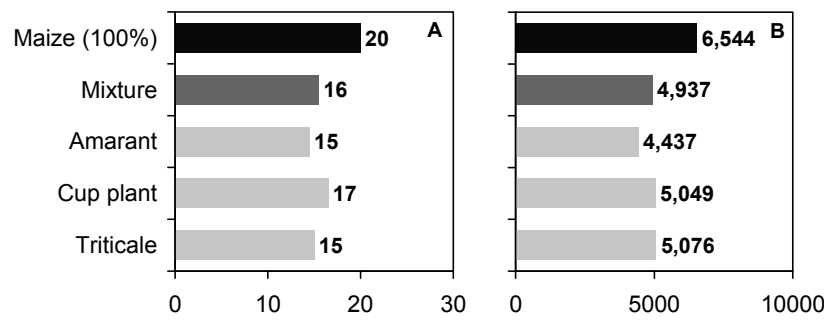

Figure 5: A. Dry matter yield ( $\mathrm{t} / \mathrm{ha}) \mathrm{B} . \mathrm{CH}_{4}$ yield $\left(\mathrm{m}^{3} / \mathrm{ha}\right)$.

In this case the empirical criteria set for low fiber content (Neutral Detergent Fiber $=\mathrm{NDF}<50 \%$ ), low lignin content (Acid Detergent Lignin $=$ ADL $<5 \%$ ) and balanced nutrient content (C:N ratio in the range 20-30) were fulfilled. One may deduce that full-scale biogas units may be successfully operated with such manure-free energy crops mixture. The calculated methane yield of the mixture was almost $5000 \mathrm{~m}_{\mathrm{CH} 4}^{3} / \mathrm{ha} /$ year. In comparison, the calculated methane yield per 
hectare for a $100 \%$ maize monoculture reached $6500 \mathrm{~m}^{3} \mathrm{CH}_{4} /$ ha/year. Therefore the theoretical methane yield per hectare of the alternative cropping system was about $20 \%$ lower than for maize monoculture. The cultivation costs might be higher for the alternative cropping system in the first year, as the perennial crop has to be established, too. However, in the long run, cultivation costs will be lower when compared to maize, as seed costs for the chosen annual crops are lower and only half of the area has to be sown. The rough calculation does not include indirect costs induced by soil erosion, loss of biodiversity and the impact of pesticides and fertilizers.

\section{Assessment of the heat sinks in the study area}

Besides the increase of sustainability with alternative cropping system (Section 3), prudent heat usage of existing and future biogas plants shall be investigated and alternatives be prospected. The essential input is the estimation of the heat demand in communes in the county of Biberach. Further, the identification of main heat sinks with potential for different grid-bound heat supply concepts, based on biogas, was focused.

\subsection{Methodology of the heat demand assessment}

For the heat demand estimation, existing building stock data, statistic data for regional economy and energy consumption by sector for the district Biberach, were analyzed. For the residential and the tertiary/industry sector geo- referenced INFAS data for building stock [16] (age, class and number of households) was used. Additionally the database of the regional economy (FIS), containing companies' addresses and numbers of their employees, arranged by the regional Chamber of Industry and Commerce [17] was included, to complete the information needed.

The heat demand of the residential sector has been estimated based on the German Building Typology [18], classifying the building stock in a matrix of 5 building types (one-family house, row house, small or big multifamily house, tower house) and 10 age classes. The heat demand of the residential sector has been built by multiplying the average heat demand of a residential building (adjusted to the regional climate conditions) by type and age with the building' average area according to the correlated data of [18] and [16]; further with the amount of respective geo-referenced buildings by [16].

The heat demand of the industry sector has been received by consideration of the statistic data on the energy consumption according the national branches taxonomy [19]. The specific energy consumption in branches on state level (without electric power) has been accounted referring to the number of employees per branch [20]. It amounts e.g. $22 \mathrm{MWh} / \mathrm{employee} \mathrm{in} \mathrm{machines}$ manufacturing, $8 \mathrm{MWh} / \mathrm{employee}$ in furniture construction or $379 \mathrm{MWh} /$ employee in paper production). This specific value has been multiplied with the 
average employee number per enterprise according the FIS data base [17] and geo-referenced by addresses.

Major regional heat sinks in the tertiary sector (trade, commerce and services) have been partially considered, i.e. kindergarten, schools, swimming pools have been geo-referenced according the INFAS data [16] and their heat demand has been estimated with help of average values (surface and heat demand) according to current literature [21-23].

\subsection{Heat demand in the region}

The built-up areas with the heat demand of buildings, aggregated in a $100 \mathrm{~m}$ raster, have been calculated and localized in a geographic information system (GIS). The values of the heat demand raster varied here between zero (by raster points without any buildings) and max. $150.000 \mathrm{MWh} / \mathrm{a}$ - doing so, the local repartition of heat sinks could be obtained (Figure 6).

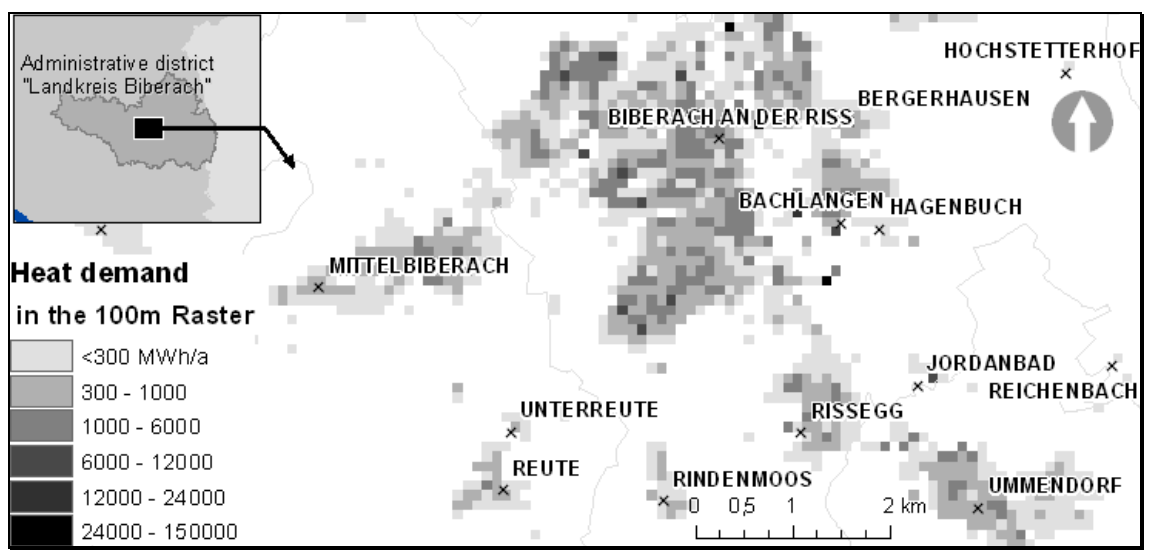

Figure 6: Detail map of the heat demand in raster of $100 \mathrm{~m}$ in communes of the Biberach district.

Additionally a ranking of communities of the county of Biberach, ordered by their annual heat demand, has been worked out: in $73 \%$ of all 45 considered communities, the estimated heat demand was below $100 \mathrm{GWh} / \mathrm{a}$. Eight communities (17\%) showed values between $100 \mathrm{GWh} / \mathrm{a}$ and $200 \mathrm{GWh} / \mathrm{a}$. The highest heat demand of $1,155 \mathrm{GWh} / \mathrm{a}$ has been accounted for the county centre Biberach, followed by the estimated heat demand for Laupheim of $470 \mathrm{GWh} / \mathrm{a}$.

In the following the heat demand density of built-up areas within the examined communities was identified as the value of the aggregated heat demand raster points in relation to the surface of the built-up areas. It shows values between $4 \mathrm{MWh} / \mathrm{ha}^{*} \mathrm{a}$ and $5.680 \mathrm{MWh} / \mathrm{ha}$ *a. For almost two third of the built-up areas the heat demand density was estimated below $300 \mathrm{MWh} / \mathrm{ha}$ *a, over one fourth showed values of between 300 and $700 \mathrm{MWh} / \mathrm{ha}$ *a. 


\section{Techno-economic analysis of alternative heat supply systems for model communities in the Biberach district}

For the purpose of investigating heat networks (district heating supplied by biogas) with micro gas grids (autonomous biogas grid from the biogas plant to the heat demand site) a techno-economic calculation model has been established. Three rural areas have been selected, according the following criteria: heat demand density bigger than $300 \mathrm{MWh} /$ ha*a (see Section 5), distance to biogas plants under $1.000 \mathrm{~m}$ (as pre-conditions for all model areas). Further, the availability of a gas network and a location in a neighborhood of an industry zone was considered. The most relevant parameters influencing heat generation costs could be identified.

In respect of the heat demand conditions in the considered model areas (different access rate of buildings), the optimal solution for each study case could be shown. The specific heat generation costs varied between $4.47 € \mathrm{ct} / \mathrm{kWh}$ $(100 \mathrm{ct}=1 €)$ to $14.52 \mathrm{ct} / \mathrm{kWh}$ for the heat pipe grid system and between $4.87 \mathrm{ct} / \mathrm{kWh}$ and $14.49 \mathrm{ct} / \mathrm{kWh}$ for micro gas grid in the considered areas.

Several patterns can be concluded. First, the network-dependent investment costs are determined by the length of the main pipe (in terms of the distance between the existing biogas production plant and the supplied area). In particular, the advantages of the micro gas grid increase with the growing length of the main pipe, because of lower specific civil engineering costs (Figure 7). Secondly, the net-independent investment costs of micro gas grids (e.g. gas treatment and gas compressor) are higher than the net-independent investment costs for heat pipe grid systems in the considered cases - they overbalance the advantages of the network-dependent investment costs.

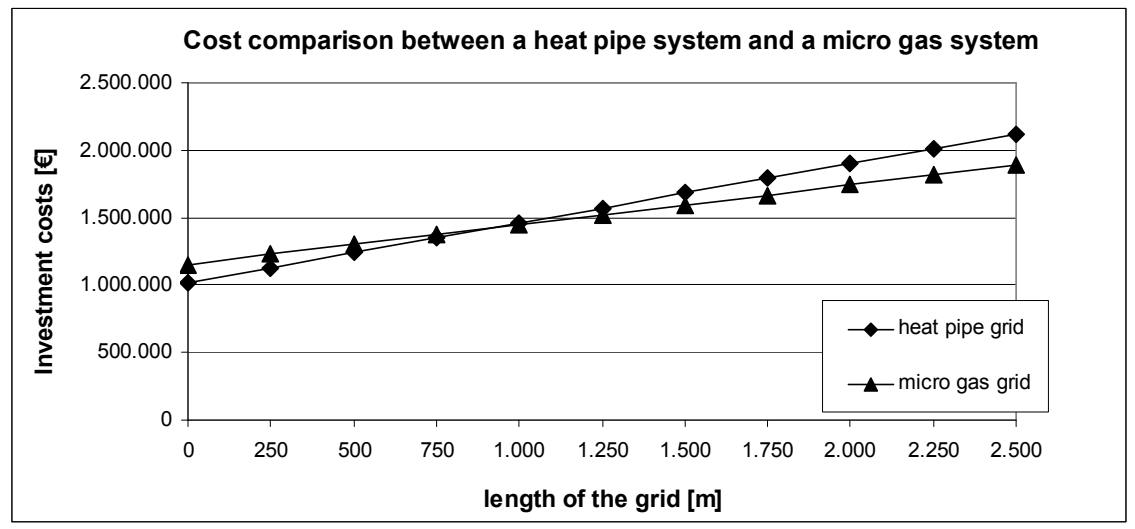

Figure 7: Comparison of investment costs between a micro gas grid and a heat pipe grid in relation to their length.

In most considered cases the biogas potential can cover only partially the local heat demand, the remaining heat demand have to be supplied by other fuels and technologies (e.g. wood or gas combustion in a peak load boiler). 


\section{Conclusion}

The project shows a high potential in alternative cropping systems and in the optimization of the local heat supply. In the following years, new crop mixtures will be tested on field and their competitiveness with the reference system maize monoculture will be economically calculated. The impacts on the environment will be monitored in a long-term study. Expected advantages concern erosion reduction, fertilizer demand and nutrient leaching mitigation as well as a decreasing use of pesticides or reduced pest infestation. Furthermore, biodiversity may be enhanced and storage capacity requirements for ensiling harvested crops may be reduced.

The heat demand analysis provides a precise picture of the potential of existing heat sinks. The techno-economic analysis of heat and gas networks shows the viability of the systems in relation to the distance, the demand site and the local biomass potential.

\section{References}

[1] EnBW: EEG-Anlagendaten in der Regelzone der EnBW Transportnetze AG, http://www.enbw.com

[2] Faustzahlen Biogas, Kuratorium für Technik und Bauwesen in der Landwirtschaft e. V. (KTBL), 2008

[3] Mapping crop distribution in administrative districts of southwest Germany using multi-sensor remote sensing data, Department of Remote Sensing, Institute of Geography, University of Würzburg, 2010 http://dx.doi.org $/ 10.1117 / 12.865113$

[4] MLR, Ministerium für Ländlichen Raum, Ernährung und Verbraucherschutz, 2010

[5] Struktur- und Regionaldatenbank, Statistisches Landesamt BadenWürttemberg, 2010 http://www.statistik.baden-wuerttemberg.de/

[6] Sachverständigenrat für Umweltfragen, Umweltschutz durch Biomasse Sondergutachten, Juli 2007, Erich Schmidt Verlag \& Co KG: Berlin, pp. 43-56, 2007.

[7] Deutsches Maiskomitee, Maisanbaufläche Deutschland in ha, 2008 und 2009 (vorläufig) nach Bundesländern und Nutzungsrichtung in ha. http://www.maiskomitee.de/web/upload/pdf/produktion/Maisanbauflaeche D_08-09.pdf

[8] Gömann, H., Kreins, P. \& Breuer, T., Deutschland - Energie-Corn-Belt Europas? Agrarwirtschaft 56(5/6), pp. 263-271, 2007.

[9] Miehe, A. K., Herrmann, A. \& Taube, F., Biogaserzeugung aus landwirtschaftlichen Rohstoffen - Monitoring des Substratanbaus und Gärrestverwertung in Schleswig-Holstein. Mitteilung der AG Grünland und Futterbau Band 9, Referate und Poster der 52. Jahrestagung der AG Futterbau und Grünland der Gesellschaft für Pflanzenbauwissenschaften, eds. Thomet, P., Menzi, H. \& Isselstein, J., AGRIDEA, pp. 313-316, 2008. 
[10] Schwabe, K., Kunert, A., Heimbach, U., Zellner, M., Baufeld, P. \& Grabenweger, G., Der Westliche Maiswurzelbohrer (Diabrotica virgifera virgifera LeConte) - eine Gefahr für den europäischen Maisanbau. Journal für Kulturpflanzen 62 (8), pp. 277-286, 2010.

[11] Laloy, E. \& Bielders, C. L., Effect of Intercropping Period Management on Runoff and Erosion in a Maize Cropping System. Journal of Environmental Quality (39), pp. 1001-1008, 2010

[12] Vetter, A. Standortangepasste Anbausysteme für Energiepflanzen - 3. Auflage. Fachargentur Nachwachsende Rohstoffe e. V: Gülzow, pp. 79-98, 2010.

[13] Willms, M., Glemnitz, M. \& Hufnagel, J., FNR-Projekt „Entwicklung und Vergleich von optimierten Anbausystemen für die landwirtschaftliche Produktion von Energiepflanzen unter den verschiedenen Standortbedinungen Deutschlands (EVA) “Teilprojekt II „Ökologische Folgewirkungen des Energiepflanzenanbaus". http://www.tll.de/vbp/eva1 /zalf_tp2.pdf

[14] Vetter, A., Heiermann, M. \&Towes, T., Anbausysteme für Energiepflanzen - optimierte Fruchtfolgen + effiziente Lösungen, DLG-Verlags-GmbH: Frankfurt am Main, pp. 81, 2009.

[15] Weiland, P. (2010) Biogas production: current state and perspectives, Applied Microbiology and Biotechnology 85:849-860.

[16] INFAS; http://www.infas-geodaten.de/

[17] Data Base of Regional Economy - Firmeninformationssystem (FIS) Firmendatenbank des Baden-Württembergischen Industrie- und Handelskammertages (IHK), http:/www.bw-firmen.ihk.de/sites /fitbw /search/detailSearch.aspx

[18] Institut Wohnen und Umwelt (IWU) Darmstadt; Deutsche Gebäudetypologie; Systematik und Datensätze; Dezember 2003

[19] Energieverbrauch des Verarbeitenden Gewerbes, Bergbau und Gewinnung von Steinen und Erden in Baden-Württemberg 2008; Statistisches Landesamt Baden-Württemberg 2010

[20] Verarbeitende Gewerbe, Bergbau und Gewinnung von Steinen und Erden in Baden-Württemberg 2008; Statistisches Landesamt Baden-Württemberg 2009

[21] Schlomann, Barbara; Gruber, Edelgard et.al; Energieverbrauch des Sektors Gewerbe, Handel, Dienstleistungen (GHD) für die Jahre 2004 bis 2006 Projektnummer 45/05 Abschlussbericht an das Bundesministerium für Wirtschaft und Technologie (BMWi) und an das Bundesministerium für Umwelt, Naturschutz und Reaktorsicherheit (BMU); Karlsruhe, München, Nürnberg; 2009

[22] Bundesministerium für Verkehr, Bau und Stadtentwicklung (BMVBS); Benchmarks für die Energieeffizienz von Nichtwohngebäuden, Vergleichswerte für Energieausweise; 2009; Berlin

[23] VDI-Richtlinie 3807 Blatt 1 Energieverbrauchskennwerte für Gebäude; 1998; Tabelle 4 